\title{
(2) \\ OPEN ACCESS \\ Top 10 research priorities for people with obstructive sleep apnoea, families and clinicians: James Lind Alliance Priority Setting Partnership
}

\author{
Donna Goodridge, ${ }^{1,2}$ Britney Duncan, ${ }^{2}$ Katherine Cowan, ${ }^{3}$ Sarah Fang, ${ }^{4}$ \\ Mark Fenton, ${ }^{1,2}$ Dave Parkalub, 2,5 Jaimie Peters, ${ }^{2,5}$ Robert Skomro, ${ }^{1,2}$ \\ Candace Skrapek, ${ }^{2,4}$ Kendra Ulmer ${ }^{6}$
}

- Additional supplemental material is published online only. To view, please visit the journal online (http://dx.doi. org/10.1136/thoraxjnl-2021 218154).

${ }^{1}$ Respirology, Critical Care and Sleep Medicine, University of Saskatchewan, Saskatoon, Saskatchewan, Canada 2Respiratory Research Centre, University of Saskatchewan, Saskatoon, Saskatchewan,

Canada

3 James Lind Alliance,

Southampton, UK

${ }^{4}$ Saskatchewan Centre for Patient-Oriented Research, Saskatoon, Saskatchewan,

Canada

${ }^{5}$ Lung Association of Saskatchewan, Saskatoon, Saskatchewan, Canada ${ }^{6}$ Canadian Centre for Health and Safety in Agriculture, University of Saskatchewan, Saskatoon, Saskatchewan, Canada

\section{Correspondence to} Dr Donna Goodridge, Respirology, Critical Care and Sleep Medicine, University of Saskatchewan, Saskatoon, Canada;

donna.goodridge@usask.ca

Received 30 August 2021 Accepted 25 December 2021

D Check for updates

C Author(s) (or their employer(s)) 2022. Re-use permitted under CC BY-NC. No commercial re-use. See rights and permissions. Published by BMJ.

To cite: Goodridge $\mathrm{D}$, Duncan B, Cowan K, et al. Thorax Epub ahead of print: [please include Day Month Year]. doi:10.1136/

thoraxinl-2021-218154

\section{ABSTRACT}

Obstructive sleep apnoea (OSA) is associated with significant comorbidity, preventable accidents and reduced quality of life. Little is known about the research priorities of patients with OSA, family members and clinicians. A James Lind Alliance research priority setting partnership was conducted. An initial survey (690 respondents who generated 1110 questions), a prioritisation survey (250 respondents), and a final workshop were used to identify the top 10 research priorities. Consensus was achieved on the top-ranked research priorities. Our results will inform the efforts of funders, researchers and policy-makers to align directly with stakeholder priorities related to OSA.

Worldwide, obstructive sleep apnoea (OSA) is estimated to affect nearly 1 billion people aged 30-69 years, with most cases remaining undiagnosed and untreated. ${ }^{1}$ Rising rates of obesity, chronic disease and population ageing increase the likelihood that OSA prevalence will continue to increase over time. ${ }^{2}$

It has been well recognised that patients make important decisions about how to best self-manage chronic conditions such as OSA
245 out of scope - removed The 8 categories

- OSA Risk, Exacerbating and Alleviating Factors (62)

Detection, Diagnosis and Treatment of OSA (348)

- CPAP Therapy in General (162)

- Effects of CPAP Therapy (23)

- Alternatives to CPAP (140)

- Adjuncts to CPAP (3)

- Equipment (137)

17 removed as agreed existing literature answered them

15 combined to form unique uncertainties

Figure 1 James Lind Alliance process overview. CPAP, continuous positive airway pressure; OSA, obstructive sleep apnoea. 
Table 1 Characteristics of patient and family member respondents

\begin{tabular}{|c|c|c|}
\hline Characteristic (n, \%) & $\begin{array}{l}\text { Identifying priorities } \\
\text { questionnaire }(\mathrm{N}=630)\end{array}$ & $\begin{array}{l}\text { Prioritisation } \\
\text { questionnaire }(\mathrm{N}=218)\end{array}$ \\
\hline \multicolumn{3}{|l|}{ Gender } \\
\hline Male & $271(43.0)$ & $86(39.4)$ \\
\hline Female & $353(56.0)$ & $104(47.7)$ \\
\hline Non-binary & $2(0.3)$ & $1(0.5)$ \\
\hline No response/prefer not to answer & $7(1.1)$ & $27(12.4)$ \\
\hline \multicolumn{3}{|l|}{ Age } \\
\hline $18-39$ & $147(23.3)$ & $20(10.5)$ \\
\hline $40-59$ & $269(42.5)$ & 90 (47.1) \\
\hline $60-69$ & $141(22.3)$ & $58(30.4)$ \\
\hline $70-79$ & $63(10.0)$ & $19(9.9)$ \\
\hline $80-89$ & $10(1.6)$ & $4(2.1)$ \\
\hline Missing & $3(0.5)$ & $27(12.4)$ \\
\hline \multicolumn{3}{|l|}{ Ethnicity } \\
\hline Caucasian & $548(86.6)$ & $176(80.7)$ \\
\hline Metis & $24(3.8)$ & $10(4.6)$ \\
\hline South-East Asian & $18(2.8)$ & $1(0.5)$ \\
\hline First Nations & $16(2.5)$ & $3(1.4)$ \\
\hline Middle Eastern & $4(0.6)$ & $1(0.5)$ \\
\hline Black & $2(0.3)$ & 0 \\
\hline Other & $17(2.7)$ & \\
\hline Missing & $4(0.6)$ & \\
\hline \multicolumn{3}{|l|}{ Respondent category } \\
\hline Diagnosed with OSA & $466(73.9)$ & $196(89.9)$ \\
\hline On waiting list for assessment & $7(1.1)$ & \\
\hline $\begin{array}{l}\text { Suspects OSA but has not sought } \\
\text { evaluation }\end{array}$ & $27(4.3)$ & \\
\hline $\begin{array}{l}\text { Family member of patient } \\
\text { diagnosed with OSA }\end{array}$ & $94(14.8)$ & $22(10.1)$ \\
\hline $\begin{array}{l}\text { Family member of person with } \\
\text { suspected OSA }\end{array}$ & $36(5.7)$ & \\
\hline Agricultural producers & $45(7.2)$ & $13(6.0)$ \\
\hline \multicolumn{3}{|l|}{ Ever prescribed treatment of OSA } \\
\hline Yes & $566(89.4)$ & NA \\
\hline No & $62(9.8)$ & \\
\hline Missing & $5(0.8)$ & \\
\hline \multicolumn{3}{|l|}{ Currently using CPAP } \\
\hline Yes, 4 or more nights per week & $420(66.4)$ & NA \\
\hline Yes, 1-3 nights per week & $16(2.5)$ & \\
\hline Yes, intermittently & $52(8.2)$ & \\
\hline No & $141(22.3)$ & \\
\hline Missing & $4(0.6)$ & \\
\hline $\begin{array}{l}\text { Duration of CPAP use } \\
\text { Under } 1 \text { year }\end{array}$ & $49(7.7)$ & NA \\
\hline $1-5$ years & $260(41.1)$ & \\
\hline $6-10$ years & $93(14.7)$ & \\
\hline$>10$ years & $85(13.4)$ & \\
\hline Missing/NA & $146(23.1)$ & \\
\hline $\begin{array}{l}\text { Reasons for going without } \\
\text { treatment }\end{array}$ & & NA \\
\hline $\begin{array}{l}\text { Unsure where to go for } \\
\text { assessment }\end{array}$ & $73(11.5)$ & \\
\hline
\end{tabular}

Continued

\begin{tabular}{lll} 
Table $1 \quad$ Continued & \\
\hline Characteristic $(\mathrm{n}, \%)$ & $\begin{array}{l}\text { Identifying priorities } \\
\text { questionnaire }(\mathrm{N}=630)\end{array}$ & $\begin{array}{l}\text { Prioritisation } \\
\text { questionnaire }(\mathrm{N}=218)\end{array}$ \\
\hline Cost of equipment & $195(30.8)$ \\
Travel distance to assessment & $42(6.6)$ \\
On waiting list & $47(4.7)$ \\
$\begin{array}{l}\text { Other reasons (free-text } \\
\text { responses) }\end{array}$ & $340(53.7)$ \\
\hline CPAP, continuous positive airway pressure; NA, not available; OSA, obstructive sleep apnoea.
\end{tabular}

and key risk factors such as obesity. ${ }^{3}$ For example, while effective continuous positive airway pressure (CPAP) use has been associated with significant improvements in many of the sequelae of OSA, ${ }^{4}$ up to $30 \%$ of patients diagnosed with OSA fail to accept CPAP therapy, ${ }^{5}$ and between $29 \%$ and $83 \%$ are estimated to be non-adherent. ${ }^{6}$ Understanding the unanswered questions of those with lived experience of OSA can make a significant contribution to the relevance of future research in this area.

Patient-oriented research, also referred to as coproduction of research, ${ }^{7}$ contributes value by engaging patients, their caregivers and families as partners in the research process in order to focus on patient-identified priorities and lead to improved patient outcomes. The James Lind Alliance (JLA) Priority Setting Partnership (PSP) brings patients, caregivers and clinicians together to identify their unanswered questions. We conducted a JLA PSP to identify the key diagnostic and treatment uncertainties related to OSA and produce the top 10 research questions in these areas.

\section{METHODS}

Our PSP took place between October 2019 and January 2021. Guided by a JLA facilitator and following the prescribed methodology, ${ }^{8}$ we adapted the process in several ways. First, in order to engage populations such as older, rural and indigenous persons, as well as those with limited access to technology, we augmented the first online elicitation survey with in-person data collection (prior to COVID-19). Second, the final workshop was conducted virtually due to COVID-19 restrictions. The Reporting guideline for PRIority Setting of health research guidelines ${ }^{9}$ ensured comprehensive and transparent reporting of this PSP.

Our steering group included: six patient partners; a Knowledge Keeper working with Indigenous Services at the Saskatchewan Health Authority; two sleep specialist physicians; a nurse who facilitated an OSA support group; a nurse manager from the local sleep lab; a nurse specialising in rural health; a patient engagement specialist from the Saskatchewan Centre from Patient-Oriented Research; a nurse researcher and a research coordinator.

The initial Elicitation Survey was conducted between November 2019 and March 2020 in both online and paper formats. The survey was widely advertised through posters, broadcast media interviews and social media. In addition to demographic questions, the survey asked 'What questions on Obstructive Sleep Apnoea would you like to see answered by research?' Respondents submitted up to five free-text questions.

Two team members (BD and DG) independently reviewed all questions submitted, consolidating similar questions. Steering group members reviewed the consolidated questions to determine whether they adequately reflected the submitted 
questions and revised the items. Questions unrelated to diagnosis or treatment of OSA were removed. Evidence checking consisted of examining systematic reviews and clinical guidelines to determine whether the consolidated questions had been fully, partially or not answered by existing research. Questions considered fully addressed were eliminated from the pool of items for the prioritisation survey, but formed the basis for several knowledge translation products for OSA patients aimed at improving knowledge, including three animated videos. The revised questions were reviewed by the JLA facilitator $(\mathrm{KC})$ for quality assurance.

An online only (due to COVID-19 restrictions) prioritisation survey (September-December 2020) of the 39 retained questions allowed patients, family members and clinicians to rank their Top 10 questions. The highest-ranked questions chosen for each group respectively in the prioritisation survey were then discussed in an online workshop (due to COVID-19 restrictions) held in January 2021. Led by three independent JLA facilitators, patient partners and professional participation selected the final top 10 research priorities through small group discussion and plenary voting.

Figure 1 provides an overview of the JLA process for this PSP. The Elicitation survey was completed by 663 members of the public and 57 clinicians, generating a total of 1110 questions. The remaining 875 questions were combined into 71 questions, which were categorised into three themes: (1) risk, exacerbating and alleviating factors; (2) management of OSA and therapy by the healthcare system and private vendors; and (3) living well with CPAP therapy. Demographics of patient and family members respondents to both

\begin{tabular}{|c|c|}
\hline Rank & Question \\
\hline 1 & How can a diagnosis of Obstructive Sleep Apnoea (OSA) be made easier to obtain? \\
\hline 2 & $\begin{array}{l}\text { How could improved affordability and insurance coverage for OSA diagnosis and } \\
\text { treatment affect patient outcomes? }\end{array}$ \\
\hline 3 & $\begin{array}{l}\text { How can access, coordination, and quality of public services be improved for } \\
\text { persons with OSA? }\end{array}$ \\
\hline 4 & $\begin{array}{l}\text { What are important considerations when treating a patient with OSA who has } \\
\text { other chronic health conditions? }\end{array}$ \\
\hline 5 & How can OSA services to rural areas be improved? \\
\hline 6 & How can OSA services to indigenous peoples be improved? \\
\hline 7 & $\begin{array}{l}\text { Are there other therapies that could be used along with continuous positive airway } \\
\text { pressure (CPAP) to improve OSA and under what circumstances? }\end{array}$ \\
\hline 8 & $\begin{array}{l}\text { How can the treatment and care of OSA in long-term and residential care settings } \\
\text { be improved? }\end{array}$ \\
\hline 9 & $\begin{array}{l}\text { How do lifestyle changes (such as weight loss, exercise and stress reduction) affect } \\
\text { the need for ongoing CPAP treatment? }\end{array}$ \\
\hline 10 & How often should CPAP therapy be re-evaluated by a healthcare provider? \\
\hline 11 & $\begin{array}{l}\text { What should be done if the patient does not notice any difference after beginning/ } \\
\text { receiving CPAP treatment? }\end{array}$ \\
\hline 12 & What can be done to improve sleep quality for people with OSA? \\
\hline 13 & Can OSA be permanently eliminated? \\
\hline 14 & Can CPAP therapy ever be stopped and under what circumstances? \\
\hline 15 & $\begin{array}{l}\text { Apart from CPAP, what other ways (including alternative therapies and physical or } \\
\text { breathing exercises) could effectively treat OSA? }\end{array}$ \\
\hline 16 & How do bed surfaces, pillows and sleeping position affect the symptoms of OSA? \\
\hline
\end{tabular}

surveys are shown in table 1.

Priorities were identified for patient respondents, for family member respondents and for provider respondents. Within each of these three groups, questions were given points based on the number of times they were selected, resulting in a ranked order for the questions for each respondent group. A shortlist was created by taking the top 10 questions from each group's ranked order. With overlap, where there was consensus between the groups, this resulted in a shortlist of 16 questions. The JLA recommended that this was a manageable number to navigate in an online discussion. The 16 top-ranked questions were shortlisted for the final workshop which included nine patients and seven clinicians. The final top 10 questions are listed in table 2 .

This JLA PSP in OSA engaged patients with OSA, their caregivers and healthcare professionals who treat those with OSA to develop a Top 10 list of patient-oriented research questions. Given the integral role patients with OSA play in self-managing their conditions and the limited resources available to conduct research, the priorities identified in this JLA PSP can serve to guide funders and researchers to topics that are most relevant and of primary importance to patients and healthcare professionals.

Contributors DG, BD and KC conceptualised the project. DG and BD prepared the manuscript. All authors were involved in the design, analysis of data and approved the final manuscript.

Funding This work was supported by the Respiratory Research Centre, University of Saskatchewan and the Saskatchewan Centre for Patient-Oriented Research.

\section{Competing interests None declared.}

\section{Patient consent for publication Not applicable.}

Ethics approval The University of Saskatchewan Behavioural Ethics Committee provided a letter of exemption for this project in October 2019.

Provenance and peer review Not commissioned; externally peer reviewed.

Open access This is an open access article distributed in accordance with the Creative Commons Attribution Non Commercial (CC BY-NC 4.0) license, which permits others to distribute, remix, adapt, build upon this work non-commercially, and license their derivative works on different terms, provided the original work is properly cited, appropriate credit is given, any changes made indicated, and the use is non-commercial. See: http://creativecommons.org/licenses/by-nc/4.0/.

\section{REFERENCES}

1 Benjafield AV, Ayas NT, Eastwood PR, et al. Estimation of the global prevalence and burden of obstructive sleep apnoea: a literature-based analysis. Lancet Respir Med 2019;7:687-98

2 Jordan AS, McSharry DG, Malhotra A. Adult obstructive sleep apnoea. Lancet 2014;383:736-47

3 Bodenheimer T, Lorig K, Holman $\mathrm{H}$, et al. Patient self-management of chronic disease in primary care. JAMA 2002;288:2469-75.

4 Antic NA, Catcheside P, Buchan C, et al. The effect of CPAP in normalizing daytime sleepiness, quality of life, and neurocognitive function in patients with moderate to severe OSA. Sleep 2011;34:111-9.

5 Lettieri CJ, Williams SG, Collen JF, et al. Treatment of obstructive sleep apnea: achieving adherence to positive airway pressure treatment and dealing with complications. Sleep Med Clin 2017;12:551-64.

6 Truong KK, De Jardin R, Massoudi N, et al. Nonadherence to CPAP associated with increased 30-day hospital readmissions. J Clin Sleep Med 2018;14:183-9.

7 Hickey DG. The potential for coproduction to add value to research. Health Expect 2018;21:693-4

8 Alliance JL. The James Lind alliance Guidebook version 8. 2018, 2018. Available: https://www.jla.nihr.ac.uk/jla-guidebook/ [Accessed 28 Jan 2020].

9 Tong A, Synnot A, Crowe S, et al. Reporting guideline for priority setting of health research (Reprise). BMC Med Res Methodol 2019;19:243. 